\title{
Short communication: Pegbovigrastim treatment in vivo does not affect granulocyte ability to migrate to endometrial cells and kill bacteria in vitro in healthy cows
}

\author{
K. Tombácz, ${ }^{1}$ L. M. Peters, ${ }^{1}$ Y.-M. Chang, ${ }^{1}$ M. Steele, ${ }^{2 *}$ D. Werling, ${ }^{1} \dagger$ and A. J. Gibson ${ }^{1}$ \\ ${ }^{1}$ Department of Pathobiology and Population Sciences, Royal Veterinary College, Hatfield, AL9 7TA, United Kingdom \\ ${ }^{2}$ Elanco Animal Health, Eli Lilly and Company Ltd., Basingstoke, RG24 9NL, United Kingdom
}

\section{ABSTRACT}

In periparturient dairy cows, immune suppression, resulting in decreased neutrophil numbers and function, leads to increased susceptibility to postpartum conditions such as mastitis, retained placenta, and metritis. Administration of polyethylene glycol-conjugated bovine granulocyte colony stimulating factor (pegbovigrastim, Imrestor; Elanco Animal Health, Greenfield, IN) $7 \mathrm{~d}$ before and within $24 \mathrm{~h}$ of calving, effectively improves granulocyte production and function in vivo as well as in milk. A recently developed coculture assay was adapted for use with endometrial epithelial cells to assess the effects of pegbovigrastim application on directed granulocyte migration and bactericidal activity in vitro on a per-cell basis in endometrial cell cultures. Granulocytes from treated and untreated periparturient cows (6 and 5 per group, respectively) were evaluated for their ability to migrate to and kill bacteria after treatment, in context of the infected endometrium. We hypothesized that in addition to increasing the absolute concentration of circulating neutrophil granulocytes, pegbovigrastim treatment in vivo alters the ability of granulocytes to migrate to endometrial cells in vitro. The results clearly show a marked increase in the total concentration of granulocytes and monocytes between the 2 treatment groups as early as $2 \mathrm{~d}$ after the first injection, and this increased between the samples taken $2 \mathrm{~d}$ after calving. No migratory or killing differences were identified between granulocytes of both groups, suggesting that pegbovigrastim-induced granulocytes were as effective as non-induced cells. This may also be due to the absence of negative energy balance in the study animals and leads us to conclude that the positive effects seen in vivo are most likely based on

Received March 4, 2019

Accepted May 20, 2019.

*Present address: Inspire Cattle Solutions, Winslow, United Kingdom.

†Corresponding author: dwerling@rvc.ac.uk the larger number of granulocytes present rather than a direct effect of pegbovigrastim treatment on the functionality of cells for the parameters tested in this study. Key words: granulocyte, pegbovigrastim, endometrial cell, bacterial killing, periparturient period

\section{Short Communication}

Puerperal metritis and postpartum endometritis are prevalent conditions in dairy cattle, compromising animal welfare, leading to economic damage by reducing milk production, and causing delayed fertility or infertility. In most cases, these conditions are caused by bacterial infections, facilitated by the presence of tissue damage caused by retained placenta, stillbirth, twins, or caesarean section, and aggravated by the innate immune response of the host to bacteria and endotoxin (Carneiro et al., 2016). Treatment of puerperal uterine disease relies heavily on antibiotics, and, although in some cases necessary for the welfare of the animal, the results are unreliable (Pyörälä et al., 2014). Given the increasing drive to reduce use of antibiotics in food-producing animals, new treatment possibilities are currently being investigated that affect immune cell subsets. The first immune cells responding to damage signals from compromised tissue and infection are polymorphonuclear cells. These cells are recruited predominantly by chemokine (C-X-C motif) ligand 8 (CXCL8 or IL-8), produced as a direct response to innate recognition of gram-negative bacterial infection by a variety of cells, including endothelial cells (Cronin et al., 2016).

Periparturient dairy cows experience a fluctuation in neutrophil count and decrease in function, starting before calving, remaining low and slowly reaching normal levels again by the fourth week of lactation (Kehrli et al., 1989). This phenomenon is associated with increased susceptibility to postpartum conditions, including retained placenta, acute puerperal metritis, and chronic endometritis (Kehrli et al., 1991; Detilleux et al., 1995; Hammon et al., 2006). The immunosup- 
pression results from both physiological (maintaining pregnancy) and pathophysiological events (negative energy balance). Elevated ketone bodies can directly impair some neutrophil functions, increasing disease susceptibility (Hoeben et al., 1997, 2000; Grinberg et al., 2008).

Prophylactic use of bovine granulocyte-colony stimulating factor (G-CSF) has the potential to preemptively increase neutrophil numbers and modulate their function ahead of parturition (Kehrli et al., 1991). Pegbovigrastim (Imrestor Elanco Animal Health, Greenfield, IN), a form of G-CSF covalently bound to polyethylene-glycol to increase its half-life, is effective in maintaining increased neutrophil granulocyte levels, compensating for decreased bacterial killing (Kimura et al., 2014). In addition, pegbovigrastim has been shown to have an influence on gene expression in neutrophils, affecting gene families related to neutrophil function, migration, interaction with pathogens, and cellular survival (Heiser et al., 2018).

As well as reducing the incidence of clinical and experimental mastitis (Powell et al., 2018), pegbovigrastim treatment decreased the risk of failure to return to estrus within $80 \mathrm{~d}$ of calving (Canning et al., 2017). A recent study found a reduction in the incidence of retained placenta and mastitis as a result of label use of pegbovigrastim; however, metritis was reported to occur more frequently in treated animals (Ruiz et al., 2017). In a different study, pegbovigrastim treatment was shown to reduce the incidence of acute puerperal metritis in primiparous dairy cows, as well as the number of antibiotic doses required for treatment (Freick et al., 2018). An increasing body of clinical data are available on the in vivo effects of pegbovigrastim use (Zinicola et al., 2018); however, its action on granulocytes on a per-cell basis is yet to be determined.

The objective of this study was to investigate the effects of Imrestor (pegbovigrastim; Elanco Animal Health, Greenfield, IN) on bacterial clearance in the context of the endometrium of cows on a per-cell basis. Blood-derived granulocytes collected from pegbovigrastim- or placebo-treated periparturient animals were examined in vitro in a newly developed coculture assay to observe their migration and bactericidal activity toward infected endometrial epithelial cells.

Our study was designed to compare functional differences between granulocytes isolated from periparturient cattle treated with pegbovigrastim and placebo. In our experience, a minimum of 6 biological repeats is necessary to overcome the natural variation in animal responsiveness to obtain significant $P$-values (with significance set at $P=0.05$ ) with regard to cytokine production and bacterial killing (Conejeros et al., 2015; Joekel et al., 2015; Gibson et al., 2016; Jensen et al.,
2016). The study was conducted at the Royal Veterinary College's Bolton Park (Potters Bar, UK) research and teaching farm, under the authority of the UK Animal Scientific Procedures Act (1986). Although no formal quality standard is claimed, the study was conducted in line with the principles of Good Clinical Practice Guidelines, and laboratory work was conducted in accordance with the Research Councils UK Policy and Guidelines on the Governance of Good Research Conduct.

Animals $(\mathrm{n}=12)$ enrolled in the study (autumn 2016 to spring 2017) were pregnant, multiparous HolsteinFriesian cows from the herd at the study site. Individual animals were identified by the unique number on their official primary ear tag and were also marked as study participants using colored tail tape. All study cows received a physical examination, including assessment of the respiratory, cardiovascular, gastrointestinal, musculoskeletal, and reproductive systems, as well as skin, udder, and teats. The physical examination included $\mathrm{BCS}$, pulse rate, respiration rate, and a rectal temperature conducted by a licensed veterinarian or trained designee approximately $7 \mathrm{~d}$ before their anticipated calving date. All animals had BCS between 2.5 and 3.5 (Wildman et al., 1982). Animals exhibiting abnormal clinical signs that could be anticipated to affect the expected calving or uterine health, and cattle undergoing any surgical or medical treatment $30 \mathrm{~d}$ before the trial, as well as animals carrying more than one calf, were not enrolled in the study.

The experimental unit for all variables was the individual animal. A treatment administrator allocated animals to treatment or placebo groups using a random selection program written in $\mathrm{R}$ and delivered the assigned treatments. Cows in the treatment group received 2 doses of Imrestor (Elanco Animal Health, Basingstoke, UK) as indicated in the product directions. Animals in the placebo group were injected with the same volume of sterile saline (Steripod, Mölnlycke Health Care, Gothenburg, Sweden) subcutaneously. Treatment data were stored in a secure location, and the scientists taking the blood sample as well as conducting the in vitro assessments were kept blinded until completion of the statistical analysis. Excluding one cow in the placebo group due to calving outside of the prescribed treatment window of $17 \mathrm{~d}, 11$ animals finished the study. One animal gave birth overnight between d 17 and 18 and was included in the analysis described in this paper.

Calving dates (study d 0) were estimated based on service date records. Nine days before anticipated calving (study day -9), whole blood and serum samples were collected, using the Vacutainer system with EDTA-treated and plain tubes (Becton Dickinson, 
Franklin Lakes, NJ). The EDTA blood was submitted to the Diagnostic Laboratories of the Royal Veterinary College for complete blood count (CBC) using an automated Advia 2120i system (Siemens, Cambridge, United Kingdom) and microscopic blood smear analysis with manual differential count. Serum samples were submitted for measurement of fatty acids to the Animal and Plant Health Agency laboratory (Shrewsbury, Shropshire, UK). Animals identified as having fatty acid levels above $400 \mu \mathrm{mol} / \mathrm{L}$ (Oetzel, 2003) were removed from the study. On study $\mathrm{d}-7$, the animals received their first treatment. Health observations were made daily from $d-7$ until completion of the analysis. On $\mathrm{d}-5$, an additional EDTA blood sample was collected and submitted for hematological analysis as described above. Within $24 \mathrm{~h}$ of actual calving (study d 0), the second treatment was administered, and $2 \mathrm{~d}$ later (study day +2 ), $24 \mathrm{~mL}$ of EDTA blood was collected for hematological analysis and to isolate granulocytes for setting up in vitro functional assays. $\beta$-Hydroxybutyric acid testing was also performed on all sampling days, using fresh whole blood, with the Precision Xtra Blood Glucose and Ketone Monitoring System (Precision) with Precision Xtra Blood Ketone Test Strips (Abbott, Maidenhead, United Kingdom).

The in vitro assessments of granulocyte function were split into 2 sections, measuring bactericidal activity and directed migratory function of granulocytes. Granulocytes were isolated by density centrifugation of EDTA blood (Muñoz-Caro et al., 2015a,b) collected by venepuncture of the jugular vein from study animals 2 d after calving. Granulocyte isolation was started within $1 \mathrm{~h}$ of sampling in all cases. After cell separation and counting, cell concentrations were set to $2 \times 10^{6}$ per $\mathrm{mL}$ for each sample, and cells were passed on to another scientist, blinded to the original cell counts, to set up the migration and bactericidal assays.

The bacterial strain used for in vitro functional assays was Escherichia coli strain MS499, which has recently been described as a prototypic endometrial pathogenic E. coli strain (Goldstone et al., 2014a,b). The E. coli MS499 was freshly plated from cryopreserved stock every week. For each migration and bactericidal assay, single colonies were selected and cultured, then diluted appropriately to ensure a multiplicity of infection (MOI) of 10 with regard to granulocyte numbers.

Primary bovine endometrium epithelial cells were cultured using uteruses collected from 2 clinically healthy Holstein-Friesian cows postmortem at an abattoir (Dawn Cardington, Bedford, UK). Endometrial cultures, consisting of epithelial $(>95 \%)$ and stromal cells were isolated using the differential attachment plating method after trypsin-collagenase digestion of endometrium tissue, as described elsewhere (Cheng et al., 2013). Cells were cultured to at least $75 \%$ confluency in anticipation of calving. Primary endometrium cultures from at least 2 animals were used in duplicates for each assay condition.

General migratory function and migration toward compromised epithelial cells were assessed by placing granulocytes $\left(1 \times 10^{6}\right)$ into the upper chamber of a transwell system (24-well plate) with a pore size of 3.0 $\mu \mathrm{m}$ (Greiner Bio One, Monroe, NC). Granulocytes migrated through these pores toward stimuli in the lower chambers of the plates, where the following conditions were present: (1) a monolayer of primary endometrium culture, (2) a monolayer of primary endometrium culture infected with $E$. coli MS499 at an MOI of 10 relative to the number of granulocytes, (3) E. coli MS499 bacteria only, (4) positive migration control $(10 \mathrm{ng} / \mathrm{mL}$ recombinant bovine CXCL8), and (5) spontaneous migration control (RPMI medium only). Each condition was set up in duplicate. Migrating granulocytes were counted from the lower chamber using a FastRead chamber slide (Immune Systems Ltd., Paignton, Devon, United Kingdom) after 3 and $24 \mathrm{~h}$, by counting in 4 grids per replicate. In the bactericidal assays, granulocytes were cocultured with E. coli MS499 at a MOI of 10 for $3 \mathrm{~h}$ at $37^{\circ} \mathrm{C}$ before removing the cell culture medium. One set of cells (3-h time point) were washed twice with gentamicin $(50 \mathrm{mg} / \mathrm{mL}$, Sigma-Aldrich, St. Louis, MO) and lysed with Triton X-100 (0.1\%). Supernatants were plated for subsequent counts (cfu) by serial dilution on Luria-Bertani agar to assess the number of viable phagocytosed bacteria. Another set of cells (24-h time point) were washed twice, and gentamicin was added to granulocyte medium. These cells were cultured for a further $21 \mathrm{~h}$, followed by lysis. Lysates were plated for cfu counts as described above.

The full reproducible protocols of in vitro migration and bactericidal assays are detailed in Supplemental Material A (https://doi.org/10.3168/jds.2019-16563). White blood cell (WBC) data were assessed for normal distribution, and biologically relevant comparisons were made between subsequent time points of data from one treatment group and between treatment groups at the same time points, using $t$-test in Prism (version 5; GraphPad Software, La Jolla, CA).

The blood tests performed at $\mathrm{d}-9,2 \mathrm{~d}$ before the first treatment, confirmed that all animals met the inclusion criteria regarding fatty acid levels, and no significant differences in fatty acid values were observed between animals enrolled in either study group (Figure 1A).

Pegbovigrastim treatment increased the overall WBC concentration, as well as the concentration of circulating neutrophil granulocytes and monocytes, but did not affect the concentration of circulating lymphocytes. At $\mathrm{d}-9,2 \mathrm{~d}$ before the first treatment, there were no sig- 


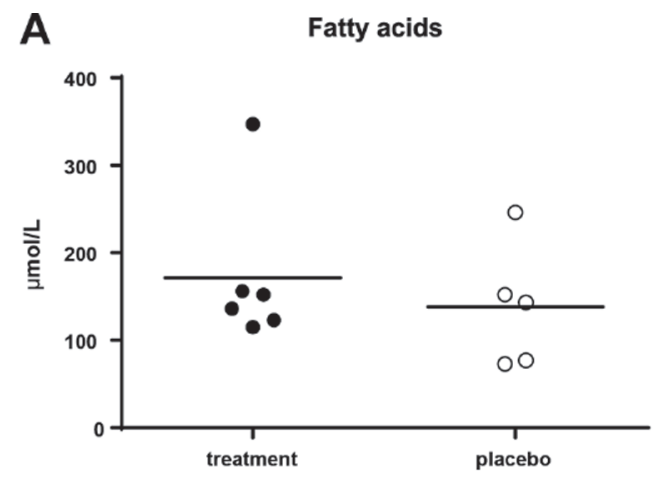

C

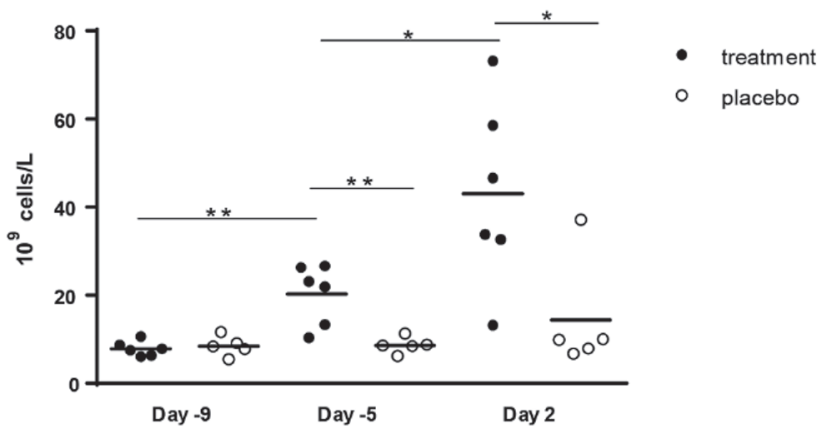

E

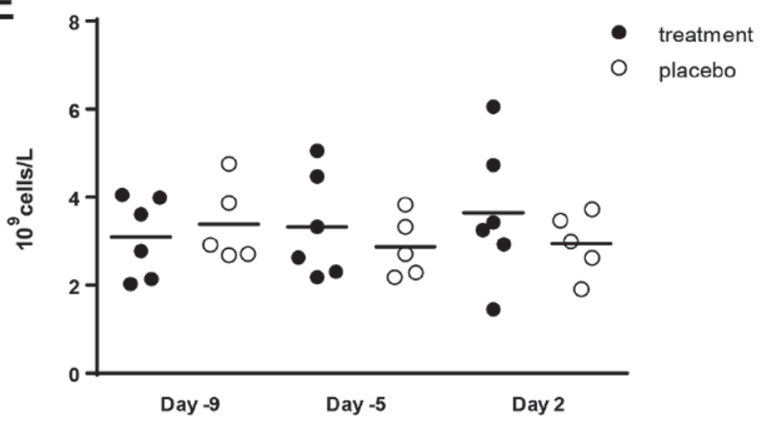

B $\quad$ BHB

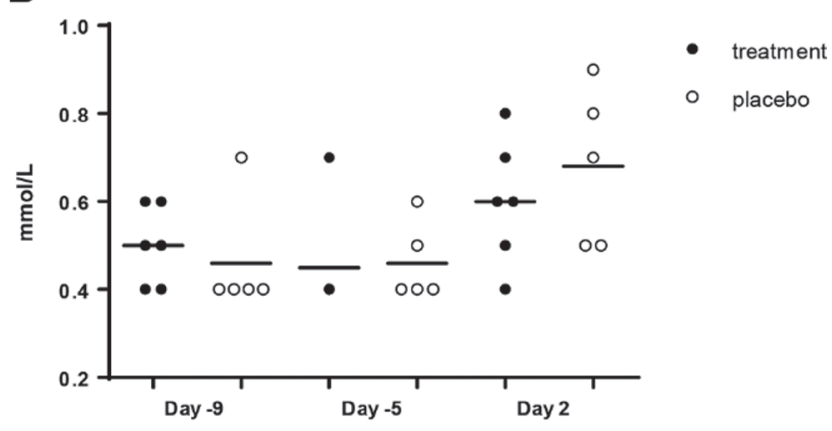

Deutrophilgranulocytes
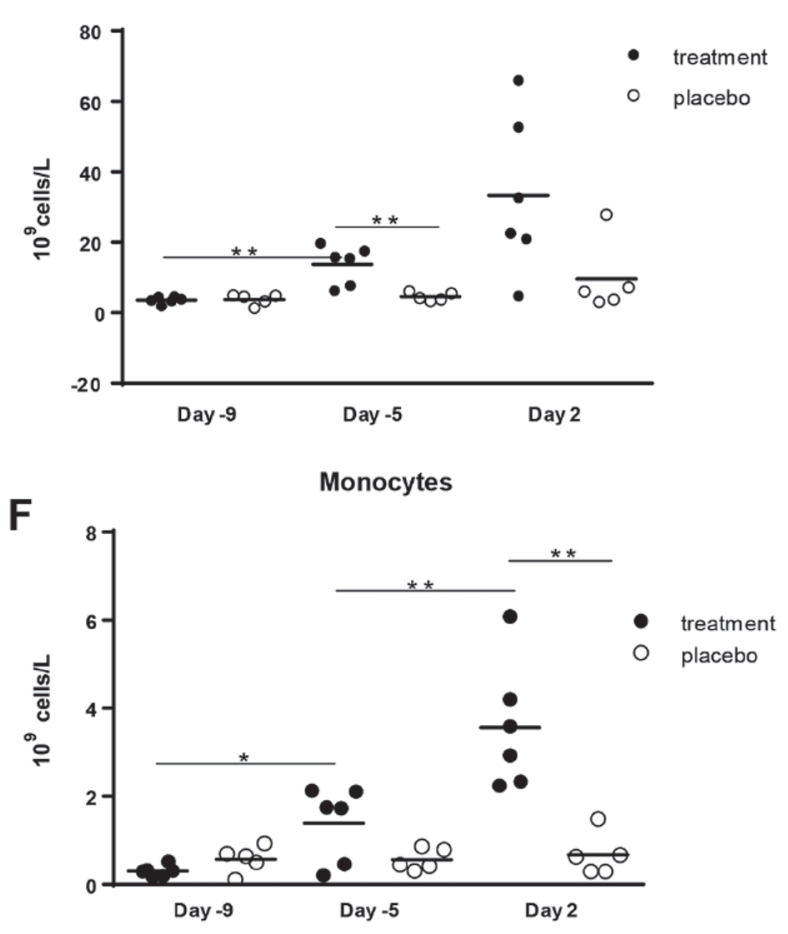

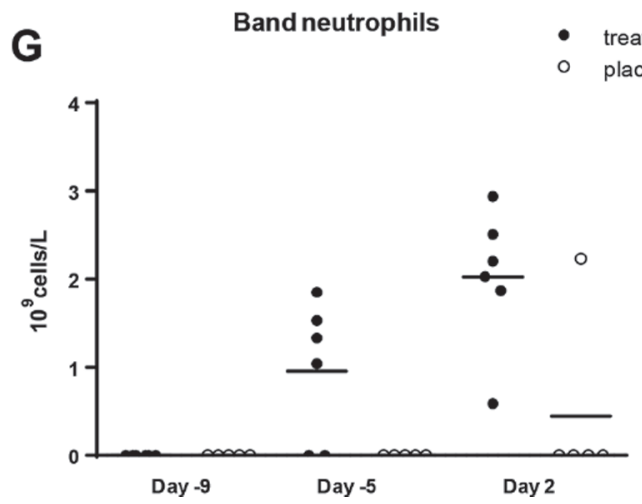

Figure 1. Ex vivo parameters measured in study groups. Dot plot diagram showing (A) fatty acid levels measured in study groups 9 d before estimated parturition, (B) BHB levels measured at 3 time points, (C) white blood cells, (D) neutrophil granulocytes, (E) lymphocytes, (F) monocyte concentrations measured at 3 time points, and ( $\mathrm{G}$ ) dot plot of band neutrophil concentrations measured in study groups. Group mean and SD values are listed in Supplemental Material B (https://doi.org/10.3168/jds.2019-16563) for each parameter. Asterisks show level of significance: ${ }^{*} P<0.05 ; * * P<0.01$. 
nificant differences for the total concentration of WBC, neutrophil granulocytes, monocytes, or lymphocytes (Figure $1 \mathrm{C}-\mathrm{F}, \mathrm{d}-9$ ). Two days after the first treatment, at $\mathrm{d}-5$, WBC concentration, as well as concentration of circulating neutrophil granulocytes and monocytes, but not that of lymphocytes, were increased in treated animals. These concentrations increased even further by the last sampling (d 2). In pegbovigrastim-treated animals, the increase in total WBC concentration was significant between all time points $(P<0.01$ from $\mathrm{d}-9$ to -5 , and $P=0.03$ from $\mathrm{d}-5$ to 2 ). Differences were also significant between treated and placebo groups at both time points after the first treatment $(P<0.01$ on $\mathrm{d}-5$, and $P=0.03$ on $\mathrm{d} 2$ ). The elevation of total WBC concentration was reflected in neutrophil and monocyte concentration, with significant increase in neutrophil granulocyte concentrations compared with before treatment $(\mathrm{d}-5, P<0.01)$ and placebo counts $(\mathrm{d}-5, P<0.01)$. Monocyte concentration showed significant responses to treatment $(P=0.01$ by $\mathrm{d}-5$, and $P<0.01$ by d 2$)$, reaching a significant difference to cells from placebo-treated animals on d $2(P<0.01)$. In contrast, no significant increases in the total concentration of monocytes and granulocytes were seen in the control group at any time point.

Interestingly, our results demonstrated a clear increase in absolute numbers of both myeloid cell subsets (and therefore also WBC) in pegbovigrastim-treated animals as early as $2 \mathrm{~d}$ after the first treatment, even in this small cohort of animals. However, we note that this effect was not homogeneous in all animals in our study, as one animal did not respond to the same extent.

Contrary to results in other studies (Kimura et al., 2014), using our study protocol, we did not see a decrease in WBC and neutrophil granulocyte concentration in placebo-treated control animals or an increase in circulating lymphocytes in pegbovigrastim-treated animals, as described by Powell et al. (2018). Because, genetically, all animals used in our study were highproducing Holstein-Friesian dairy cattle, the maintenance of leukocyte numbers throughout parturition was probably due to a less marked negative energy balance, caused by the management practices on the smallerscale study farm where the trial was conducted. This is in line with the result that none of the animals had fatty acid levels above $400 \mu \mathrm{mol} / \mathrm{L}$ (Figure 1A), nor BHB levels above $1.4 \mathrm{mmol} / \mathrm{L}$ (Figure 1B), indicating the absence of subclinical ketosis (Oetzel, 2003).

Alongside fully mature granulocytes, band neutrophils were also released into circulation in 4 out of 6 animals after the first treatment, and in all cows after the second pegbovigrastim treatment (Figure 1G). In 1 treated animal, metamyelocytes appeared in peripheral blood on d 2. In contrast, band neutrophils were mea- sured in only one animal in the placebo control group after the second injection. This is a known effect of GCSF treatment in cattle (Kehrli et al., 1991; Detilleux et al., 1995).

Bacterial survival was not affected by pegbovigrastim treatment on a per-cell basis (Figure 2A). Because granulocytes from pegbovigrastim-treated animals have been described as showing higher myeloperoxidase activity, which could increase bacterial killing, we were interested to assess differences in bactericidal activity of granulocytes exposed to $E$. coli bacteria from either treatment group. Neither at $3 \mathrm{~h}$ incubation nor at 24 $\mathrm{h}$ did the amounts of surviving bacteria recovered from lysed granulocytes show a significant difference, indicating similar bactericidal rates between both groups.

Granulocytes from either treated or untreated cows were also assessed for their ability to migrate toward isolated endometrial cells, E. coli-infected endometrial cells, E. coli alone, or CXCL8. Overall, the number of granulocytes that migrated under any condition was numerically greater (no significant differences) after 24 $\mathrm{h}$ compared with those values obtained in the same condition after $3 \mathrm{~h}$ (Figures 2B, 2C). The number of migrated granulocytes was greater under all conditions tested compared with the negative control (using medium alone); however, no significant differences between granulocytes isolated from pegbovigrastim-treated or untreated animals were seen at $3 \mathrm{~h}$ or $24 \mathrm{~h}$. It was recently described that pegbovigrastim treatment increased expression of genes involved in granulocyte migration and function (Heiser et al., 2018). However, because these changes were not confirmed by flow cytometry or ex vivo functional assays, our data may not be regarded as contradictory to the observations of Heiser et al. (2018).

To determine whether cells generated from uteruses of different animals affected migration, primary cells from 2 animals were used. These animals were in slightly different stages of their estrous cycles: one just after ovulation, with corpus hemorrhagicum present, and the other one having a well-developed corpus luteum. Differences in the number of migrating granulocytes were assessed between the results obtained for cells generated from treated or untreated cows, to either endometrial epithelium cells alone or to endometrial cells infected with E. coli strain MS499, at 3 as well as $24 \mathrm{~h}$, in a $t$-test paired for each condition. We detected no significant difference between the results of the 2 endometrium cultures $(P=0.7114$, mean of differences $=1.6 \times 10^{5}$ migrated cells $/ \mathrm{mL}$; data not shown $)$. The source of tissue did not affect the outcome of the results obtained, in line with observations that in vitro cultures of endometrial epithelial and stromal cells have been described to mount innate immune responses to 
E. coli independently of the stage of estrous cycle (Saut et al., 2014).

Pegbovigrastim is currently described as having its most beneficial effects during the period of negative en-
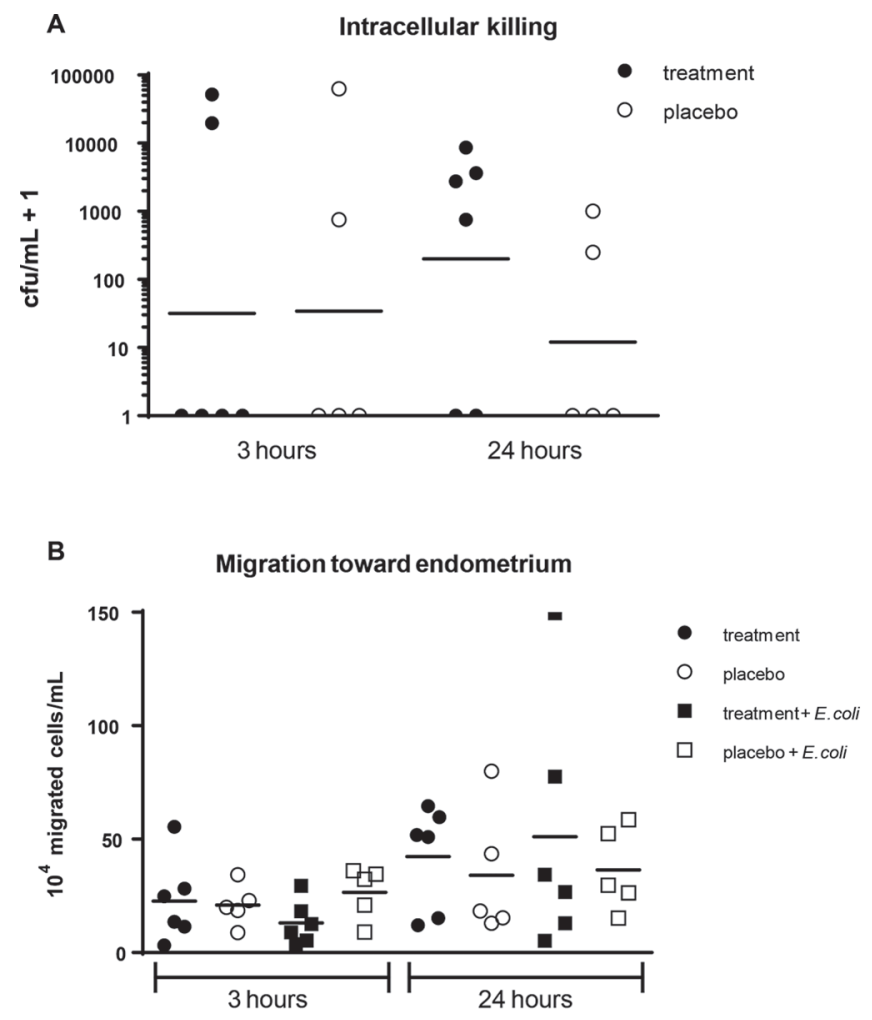

C

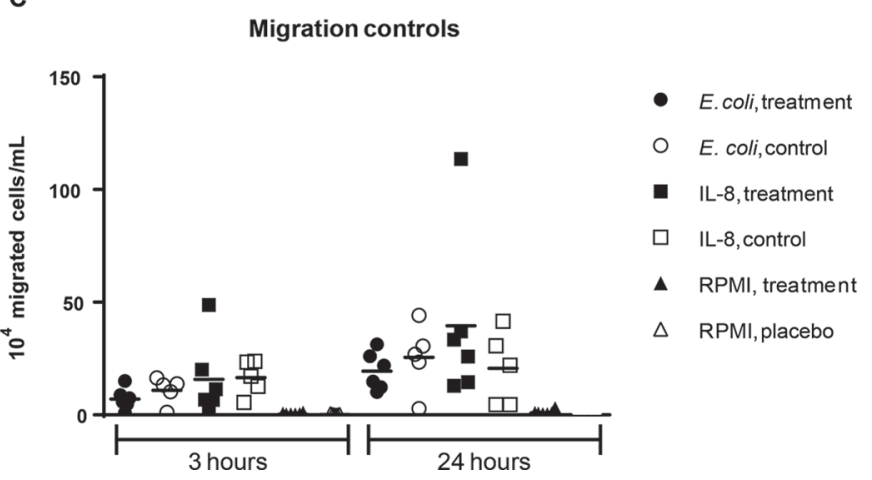

Figure 2. In vitro assay results. (A) Bactericidal assay: dot plot showing individual values and geometric means of colony-forming units $(\mathrm{cfu}+1) / \mathrm{mL}$ of Escherichia coli MS499 surviving intracellular killing after 3 and $24 \mathrm{~h}$ of incubation. For the purpose of representing zero values on a logarithmic scale, 1 was added to all mean counts $(\mathrm{cfu}+1)$. (B) Dot plot showing migration of granulocytes from pegbovigrastim- and placebo-treated animals toward endometrium and infected endometrium. (C) Results of migration assay controls: dot plot of migrated cells toward E. coli MS499, $10 \mathrm{ng} / \mathrm{mL}$ IL-8, and medium-only control (RPMI). Group mean and SD values are listed in Supplemental Material C (https://doi.org/10.3168/jds.2019-16563) for each parameter. ergy balance, when neutrophil numbers are decreased. It may be possible that a negative energy balance causes oxidative stress, inhibiting granulocyte function (Kuwabara et al., 2015), which could be exacerbated by the presence of ketone bodies during this period (Hoeben et al., 1997). However, in general, our observations indicate that granulocytes generated from both study groups are readily able to migrate to endometrial cells in a transwell system. Furthermore, we observed no differences in granulocyte function between negative controls (cells incubated with medium alone) and cells exposed to treatment. Our results do not indicate decreased or enhanced function of granulocytes isolated from pegbovigrastim-treated cows compared with granulocytes isolated from control-treated cows on a per-cell basis. In our study, placebo-treated animals maintained WBC concentrations throughout the experiment, and granulocytes remained functional for the parameters tested. Because our study was performed using healthy cows, it remains to be seen in future studies whether effects of pegbovigrastim treatment on neutrophil functionality might be different in animals with negative energy balance, hypocalcemia, or any other form of stress, or in animals with reduced neutrophil concentrations.

\section{ACKNOWLEDGMENTS}

We thank Daniel Hampshire, Marie-Christine Bartens (Royal Veterinary College, Hatfield, United Kingdom), and Dawn Meats (Bedford, United Kingdom) for technical assistance. Furthermore, we thank the staff of the Royal Veterinary College Bolton Park farm (Potters Bar, UK) for their collaboration and help, especially Charlotte Verity. The study was funded by a grant to D. W. from Elanco Animal Health (Basingstoke, United Kingdom), covering salary for K. T. and costs of consumables. This manuscript represents publication PPS_01959 of the Royal Veterinary College.

\section{REFERENCES}

Canning, P., R. Hassfurther, T. TerHune, K. Rogers, S. Abbott, and D. Kolb. 2017. Efficacy and clinical safety of pegbovigrastim for preventing naturally occurring clinical mastitis in periparturient primiparous and multiparous cows on US commercial dairies. J. Dairy Sci. 100:6504-6515.

Carneiro, L. C., J. G. Cronin, and I. M. Sheldon. 2016. Mechanisms linking bacterial infections of the bovine endometrium to disease and infertility. Reprod. Biol. 16:1-7.

Cheng, Z., D. R. Abayasekara, F. Ward, D. M. Preece, K. A. Raheem, and D. C. Wathes. 2013. Altering n-3 to n-6 polyunsaturated fatty acid ratios affects prostaglandin production by ovine uterine endometrium. Anim. Reprod. Sci. 143:38-47.

Conejeros, I., A. J. Gibson, D. Werling, T. Muñoz-Caro, C. Hermosilla, A. Taubert, and R. A. Burgos. 2015. Effect of the synthetic Toll-like receptor ligands LPS, Pam3CSK4, HKLM and FSL-1 in the function of bovine polymorphonuclear neutrophils. Dev. Comp. Immunol. 52:215-225. 
Cronin, J. G., V. Kanamarlapudi, C. A. Thornton, and I. M. Sheldon. 2016. Signal transducer and activator of transcription-3 licenses Toll-like receptor 4-dependent interleukin (IL)-6 and IL-8 production via IL-6 receptor-positive feedback in endometrial cells. Mucosal Immunol. 9:1125-1136.

Detilleux, J. C., M. E. Kehrli Jr., J. R. Stabel, A. E. Freeman, and D. H. Kelley. 1995. Study of immunological dysfunction in periparturient Holstein cattle selected for high and average milk production. Vet. Immunol. Immunopathol. 44:251-267.

Freick, M., M. Zenker, O. Passarge, and J. Weber. 2018. Reducing the incidence of acute puerperal metritis in primiparous cows by application of pegbovigrastim in a Holstein dairy herd. Vet. Med. (Praha) 63:151-160.

Gibson, A. J., S. Woodman, C. Pennelegion, R. Patterson, E. Stuart, N. Hosker, P. Siviter, C. Douglas, J. Whitehouse, W. Wilkinson, S. A. Pegg, B. Villarreal-Ramos, and D. Werling. 2016. Differential macrophage function in Brown Swiss and Holstein Friesian cattle. Vet. Immunol. Immunopathol. 181:15-23.

Goldstone, R. J., R. Popat, H. J. Schuberth, O. Sandra, I. M. Sheldon, and D. G. Smith. 2014a. Genomic characterisation of an endometrial pathogenic Escherichia coli strain reveals the acquisition of genetic elements associated with extra-intestinal pathogenicity. BMC Genomics 15:1075.

Goldstone, R. J., R. Talbot, H. J. Schuberth, O. Sandra, I. M. Sheldon, and D. G. Smith. 2014b. Draft genome sequence of Escherichia coli MS499, isolated from the infected uterus of a postpartum cow with metritis. Genome Announc. 2:e00217-14.

Grinberg, N., S. Elazar, I. Rosenshine, and N. Y. Shpigel. 2008. Betahydroxybutyrate abrogates formation of bovine neutrophil extracellular traps and bactericidal activity against mammary pathogenic Escherichia coli. Infect. Immun. 76:2802-2807.

Hammon, D. S., I. M. Evjen, T. R. Dhiman, J. P. Goff, and J. L. Walters. 2006. Neutrophil function and energy status in Holstein cows with uterine health disorders. Vet. Immunol. Immunopathol. 113:21-29.

Heiser, A., S. J. LeBlanc, and S. McDougall. 2018. Pegbovigrastim treatment affects gene expression in neutrophils of pasture-fed, periparturient cows. J. Dairy Sci. 101:8194-8207.

Hoeben, D., R. Heyneman, and C. Burvenich. 1997. Elevated levels of beta-hydroxybutyric acid in periparturient cows and in vitro effect on respiratory burst activity of bovine neutrophils. Vet. Immunol. Immunopathol. 58:165-170.

Hoeben, D., E. Monfardini, G. Opsomer, C. Burvenich, H. Dosogne, A. De Kruif, and J. F. Beckers. 2000. Chemiluminescence of bovine polymorphonuclear leucocytes during the periparturient period and relation with metabolic markers and bovine pregnancyassociated glycoprotein. J. Dairy Res. 67:249-259.

Jensen, K., I. J. Gallagher, A. Kaliszewska, C. Zhang, O. Abejide, M. P. Gallagher, D. Werling, and E. J. Glass. 2016. Live and inactivated Salmonella enterica serovar Typhimurium stimulate similar but distinct transcriptome profiles in bovine macrophages and dendritic cells. Vet. Res. 47:46.

Joekel, D., P. Hinse, M. K. Raulf, S. Schicht, W. Baumer, D. Werling, E. Kremmer, and C. Strube. 2015. Vaccination of calves with yeast- and bacterial-expressed paramyosin from the bovine lungworm Dictyocaulus viviparus. Parasite Immunol. 37:614-623.
Kehrli, M. E. Jr., J. P. Goff, M. G. Stevens, and T. C. Boone. 1991. Effects of granulocyte colony-stimulating factor administration to periparturient cows on neutrophils and bacterial shedding. J. Dairy Sci. 74:2448-2458.

Kehrli, M. E. Jr., B. J. Nonnecke, and J. A. Roth. 1989. Alterations in bovine neutrophil function during the periparturient period. Am. J. Vet. Res. 50:207-214

Kimura, K., J. P. Goff, P. Canning, C. Wang, and J. A. Roth. 2014. Effect of recombinant bovine granulocyte colony-stimulating factor covalently bound to polyethylene glycol injection on neutrophil number and function in periparturient dairy cows. J. Dairy Sci. 97:4842-4851.

Kuwabara, W. M., L. Zhang, I. Schuiki, R. Curi, A. Volchuk, and T. C. Alba-Loureiro. 2015. NADPH oxidase-dependent production of reactive oxygen species induces endoplasmatic reticulum stress in neutrophil-like HL60 cells. PLoS One 10:e0116410.

Muñoz-Caro, T., M. Lendner, A. Daugschies, C. Hermosilla, and A. Taubert. 2015a. NADPH oxidase, MPO, NE, ERK1/2, p38 MAPK and $\mathrm{Ca} 2+$ influx are essential for Cryptosporidium parvum-induced NET formation. Dev. Comp. Immunol. 52:245-254.

Muñoz-Caro, T., S. J. Mena Huertas, I. Conejeros, P. Alarcon, M. A. Hidalgo, R. A. Burgos, C. Hermosilla, and A. Taubert. 2015b. Eimeria bovis-triggered neutrophil extracellular trap formation is CD11b-, ERK 1/2-, p38 MAP kinase- and SOCE-dependent. Vet. Res. 46:23.

Oetzel, G. R. 2003. Herd-based biological testing for metabolic disorders. In Proc. American Association of Bovine Practitioners 36th Annual Conference. Columbus, OH. https://pdfs.semanticscholar .org/ec3e/452dcd5f54b3bd77627a347fb44889d0a9c3.pdf

Powell, E. J., T. A. Reinhardt, E. Casas, and J. D. Lippolis. 2018. The effect of pegylated granulocyte colony-stimulating factor treatment prior to experimental mastitis in lactating Holsteins. J. Dairy Sci. 101:8182-8193.

Pyörälä, S., J. Taponen, and T. Katila. 2014. Use of antimicrobials in the treatment of reproductive diseases in cattle and horses. Reprod. Domest. Anim. 49(Suppl 3):16-26.

Ruiz, R., L. O. Tedeschi, and A. Sepúlveda. 2017. Investigation of the effect of pegbovigrastim on some periparturient immune disorders and performance in Mexican dairy herds. J. Dairy Sci. 100:33053317.

Saut, J. P., G. D. Healey, A. M. Borges, and I. M. Sheldon. 2014. Ovarian steroids do not affect bovine endometrial cytokine or chemokine responses to Escherichia coli or LPS in vitro. Reproduction 148:593-606

Wildman, E. E., G. M. Jones, P. E. Wagner, R. L. Boman, H. F. Troutt Jr., and T. N. Lesch. 1982. A dairy cow body condition scoring system and its relationship to selected production characteristics. J. Dairy Sci. 65:495-501.

Zinicola, M., H. Korzec, A. G. V. Teixeira, E. K. Ganda, L. Bringhenti, A. Tomazi, R. O. Gilbert, and R. C. Bicalho. 2018. Effects of pegbovigrastim administration on periparturient diseases, milk production, and reproductive performance of Holstein cows. J. Dairy Sci. 101:11199-11217. 